\title{
Indian Flat Breads: A Review
}

\author{
Shabir Ahmad Mir'1,2, Haroon Rashid Naik3 , Manzoor Ahmad Shah"1,2*, \\ Mohammad Maqbool Mir ${ }^{4}$, Muzammil Habib Wani'2, Mudassir Ahmad Bhat ${ }^{2}$ \\ ${ }^{1}$ Department of Food Science and Technology, Pondicherry University, Puducherry, India \\ ${ }^{2}$ Department of Food Technology, Islamic University of Science and Technology, Awantipora, \\ Jammu and Kashmir, India \\ ${ }^{3}$ Division of Post Harvest Technology, Sher-e-Kashmir University of Agriculture Sciences \& Technology, \\ Kashmir, Srinagar, Jammu and Kashmir, India \\ ${ }^{4}$ Division of Fruit Science, Sher-e-Kashmir University of Agriculture Sciences \& Technology, Kashmir, \\ Srinagar, Jammu and Kashmir, India \\ Email: ${ }^{\text {manzoormft@gmail.com }}$
}

Received 25 November 2013; revised 25 December 2013; accepted 4 January 2014

Copyright (C) 2014 by authors and Scientific Research Publishing Inc.

This work is licensed under the Creative Commons Attribution International License (CC BY). http://creativecommons.org/licenses/by/4.0/

(c) (i) Open Access

\begin{abstract}
Flat breads are very popular especially in those parts of the world where bread constitutes a major source of dietary protein and calories. There are several forms of flat bread, and the variation is mainly in terms of ingredient, technology, and quality. Several modifications in the formulations have been made in the recent past in order to improve the quality and delicacy of these food products. With urbanization and industrialization, the demand for ready to eat and easy to carry products resembling flat bread in appearance, but having desirable qualities of bread offers one exciting possibility to this effect. In India, wheat is one of the daily staples, consumed in the form of different flat breads such as Chapati, Parotha, Phulka, Puri and Tandoori Roti. Different wheat varieties have been used for the production of flat breads. In recent years, many researchers have tried to improve ingredient level, baking properties, organoleptic characteristics, nutritional value and extension of the shelf life of flat bread. They are usually produced from a simple recipe consisting of flour, salt and water in varying proportions, however, sometimes the manufactures also use optional ingredients like yeast fat, skim milk powder and certain additives like emulsifiers, hydrocolloids, enzymes and preservatives for quality improvement and shelf life enhancement.
\end{abstract}

\section{Keywords}

Flat Bread; Chapati; Parotha; Tandoori Roti

\footnotetext{
${ }^{*}$ Corresponding author.
} 


\section{Introduction}

In India, Pakistan, Middle East and North African countries, the extensive use of wheat (Triticum aestivum) flour for the production of flat bread has been reported in the recent literature [1] [2]. There are several forms of flat bread, and the variation is mainly in terms of composition, technology, and quality. The typical pictures of common Indian flat breads are shown in Figure 1. Although flat breads are commonly prepared from whole wheat, refined or blends with other flours are also used [3]. Several modifications in the formulations have been made in the recent past in order to improve the quality and delicacy of these food products. In India, wheat is one of the daily staples, consumed in the form of different flat breads such as Chapati, Parotha, Phulka, Puri and Tandoori Roti [4] [5].

Chapati is either leavened or unleavened flat bread consumed throughout the Indian subcontinent and other parts of Middle East. It is usually prepared from whole wheat flour and sometimes yeast and fat is also included in the formulation to improve the dough handling, mixing and textural properties [6] [7]. The product is prepared by mixing the flour with water and other ingredients to develop the dough, sheeted and baked for short time [8]. They have creamish brown color generally prepared in households, forming a cheap source of protein and energy [1] [2]. The method of preparation for Tandoori Roti is similar to Chapati. The flour is mixed with water, shortening and salt, sour dough or yeast, sheeted and baked in a tandoor and is creamish brown to brown in colour [9]. Parotha is typical Indian flat bread prepared from wheat flour, water, oil, salt while sugar and egg form optional ingredients [4] [10]. Although two types of Parotha are generally prepared in India. South Indian Parotha and North Indian Parotha differ in extraction rate of flour [4] [11]. The Parotha is creamish white to brown in color, and possesses the several distinct layers and consumed along with vegetarian or non-vegetarian dishes [4].

The flat breads are usually produced from a simple recipe consisting of flour, salt and water in varying proportions, however, sometimes the manufactures also use optional ingredients like yeast fat, skim milk powder
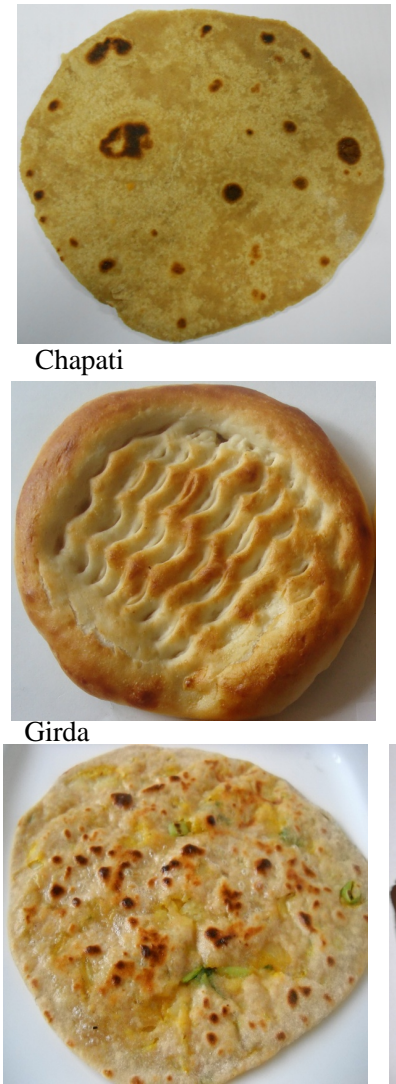

Parotha

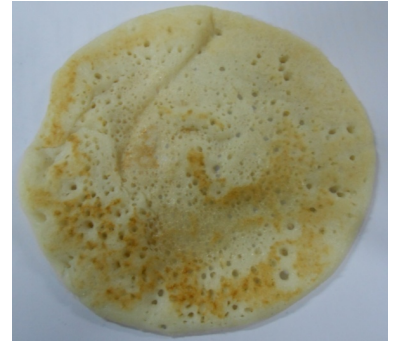

Dosai

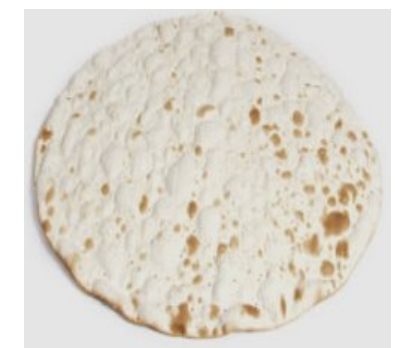

Lavash

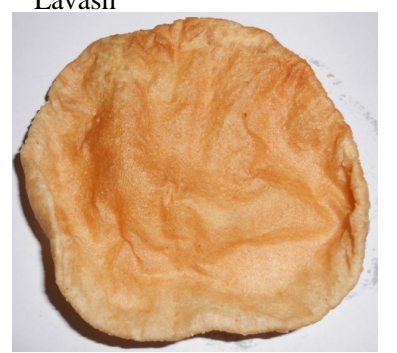

Puri

Figure 1. Common Indian flat breads. 
and certain additives for quality improvement and shelf life enhancement [11]. Flour nature and water are the most important ingredients that affect the texture, aroma and chewability of flat bread [12]. They are prepared from the flour of various extraction rate, which should have medium gluten strength, high water absorption capacity and starch damage [2] [13]. Salt in various amounts is used ranging from about $0.5 \%$ to $1.5 \%$ [5] to $2 \%$ of flour weight [14] which enhances the flavor. The leaving agents mainly used in flat bread products are yeast, sourdough and baking soda. The fermentation process is proceeded in some flat breads by mainly yeast and sourdough [15] [16]. The lipid of various concentrations $0.5 \%$ - 5\% has been added to the flat breads which improve their textural and sensory properties [9]. In addition to the numbers of emulsifiers, hydrocolloids and enzyme preparations have been added to the recipe to modify the process conditions so as to offer the consumer fresh bread at any time [3] [17] [18].

With urbanization and industrialization the consumer's demand for fresh flat breads has increased day by day, so the new technologies have been developed to cater the demand of the product which is easy to produce and economical [17]. The development of new technologies helps to understand the influence of flour characteristics, ingredients and bread production process has been essential to improve and maintain the quality characteristics of flat breads [19]. The influences of wheat variety, extraction rate, rheological properties ingredient level, mixing schedule, sheeting dimension, fermentation, proofing and baking schedules have been standardized from time to time and improved to enhance the sensory and textural quality of flat bread [5] [9] [18].

\section{Ingredients}

The formulations of flat breads differ from region to region, but the basic ingredients are flour, water, salt (sodium chloride), and naturally fermented starter dough with either baking powder or baker's yeast [17] [20] [21]. In addition, sugar, butter, vegetable shortening or non-fat dry milk may be added to enhance taste and aroma. The bread quality is only partly dependent on the quality parameters related to the raw material slected [13]. The quality of bread is a complex concept influenced by many factors: quality of wheat, properties of flour and the baking procedures employed.

Flour is the basic ingredient in a flat bread recipe as it affects the texture and sensory properties [17]. It is noteworthy that Indian wheat varieties differ strikingly in their composition and functionality as compared to wheat grown in other parts of the world [22]. Quality of flat bread is affected by the composition of flour, which is dependent on the milling characteristics and wheat variety [19]. Milling techniques differ extensively and flour of different baking quality would be expected, even using the same wheat sample and the same extraction rate. The final composition of the flour is achieved through blending of different flour fractions to produce a desired flour quality. Flours of different extraction rates give different bread types with colours from creamy white to pale brown. The loaf volume decreases when bran is added [23], but the nutritional value increases.

The most important character of wheat flour, which affects the bread quality is the total protein content [3]. Considerable work has also been reported on the influence of quality and quantity of protein fractions on Chapati characteristics [5] [24]. Many aspects of bread quality like bread area index, uniformity of thickness and crumb appearance were related to the quality and quantity of protein [25]. Although it has been observed that quality of flat bread is superior from hard wheat flour associated with medium gluten strength, high starch damage, higher water absorption capacity, good mixing and sheeting properties [13] [25].

The flour characteristics and differences in degree of damaged starch were great enough to influence the sensory qualities of whole wheat pan bread and to distinguish roller-milled versus stone-milled breads baked with wheat from the same lot. The roller-milled wheat samples had, besides a higher degree of damaged starch related to milling, higher farinograph water absorption. During dough preparation, the enzyme activity continues to increase [26] [27] and the activity of alpha-amylase and beta-amylase increase when the degree of damaged starch is higher [28]. The implication of increased enzyme activity is an observed decrease in falling number.

The amount of water used during flat bread production depends on the type of flour and bread. Approximately $50 \%$ water results in finely textured, light flat bread. Most artisan bread formulas contain anywhere from 60 to 75\%. In yeast leavened flat breads, the higher water absorption results in more carbon dioxide bubbles, and a coarse bread structure. Water used during mixing the ingredients makes possible the formation of gluten due to the hydration of proteins and alter the rheological properties [21]. The addition of bran to the flour influences its water absorbing capacity. Bran contains pentosans characterized by their high ability to absorb water [27] [29]. The flours containing the largest bran particles had increased compactness in the breads. When the bran particle 
sizes were smaller and partly connected with endosperm [30] as in stone-milled flour, the bread texture increased in deformity. High deformity of the crumb indicates poor quality of bread texture.

Salt is mainly used for flavour and taste enhancement in flat bread production. It also brings out the taste of other ingredients and helps to improve the characteristics of the bread [21]. The normal range of salt addition is about $0.5 \%$ to $3 \%$ of flour weight [3] [5]. Without salt the weak flours make wetty doughs, therefore the addition of salt improves the strength of proteins and gives good texture and better loaf volume and to convert the action of yeast for controlled action of dough. The addition of salt increased the strength and elasticity of the dough as indicated by the increased in farinograph value, mixograph peak height, cohesiveness and hardness [9]. As the salt content increased from $0.0 \%$ to $1.5 \%$, the farinograph water absorption and the mixing tolerance index decreased from $57.8 \%$ to $56.2 \%$ and 80 to $40 \mathrm{BU}$; in contrast, the stability, and the valorimeter value increased from 3.5 to 9.5 min and 48 to 54, respectively [4].

The fermentation or rising of dough are due to the leaving agents like yeast, sourdough and baking soda. Gas cells are generated with the action of leaving agents [31]. The leavening agent generate gas $\left(\mathrm{CO}_{2}\right)$ within the liquid phase, which diffuses in solution to the nuclei due to a concentration gradient. Fermentation caused by baker's yeast Saccharomyces cerevisiae is the most commonly used yeast in flat breadmaking. Due to fermentation sugar is converted to moisture and $\mathrm{CO}_{2}$. As water vapor and $\mathrm{CO}_{2}$ expand due to high temperature, they act as insulating agent preventing high rate of temperature rise of bread crumb and the possibility of excessive moisture evaporation. Baking powder the leavening agent widely used in flat bread production due to its low cost. Utilization of baking soda act as leaving agent and can change color and flavor of bread.

\section{Technology of Flat Bread}

The common flat breads of India are given in Table 1. The main ingredients that are used to create basic formula dough are flour, water, sodium chloride and leaving agent [20]. In order to convert these mix ingredients into the final product a number of operations are performed [40]. These operations are carried out in such a way that the dough posses the appropriate sensory and mechanical properties which will permit it to retain gas and thus produce a well expanded loaf of bread [41] [42]. The flow sheet for the preparation of flat breads is given in Figure 2.

Mixing is most important step in preparing flat bread during which all the ingredients are uniformly mixed to distribute equally. During dough mixing, wheat flour is hydrated, and the discrete masses of gluten proteins are

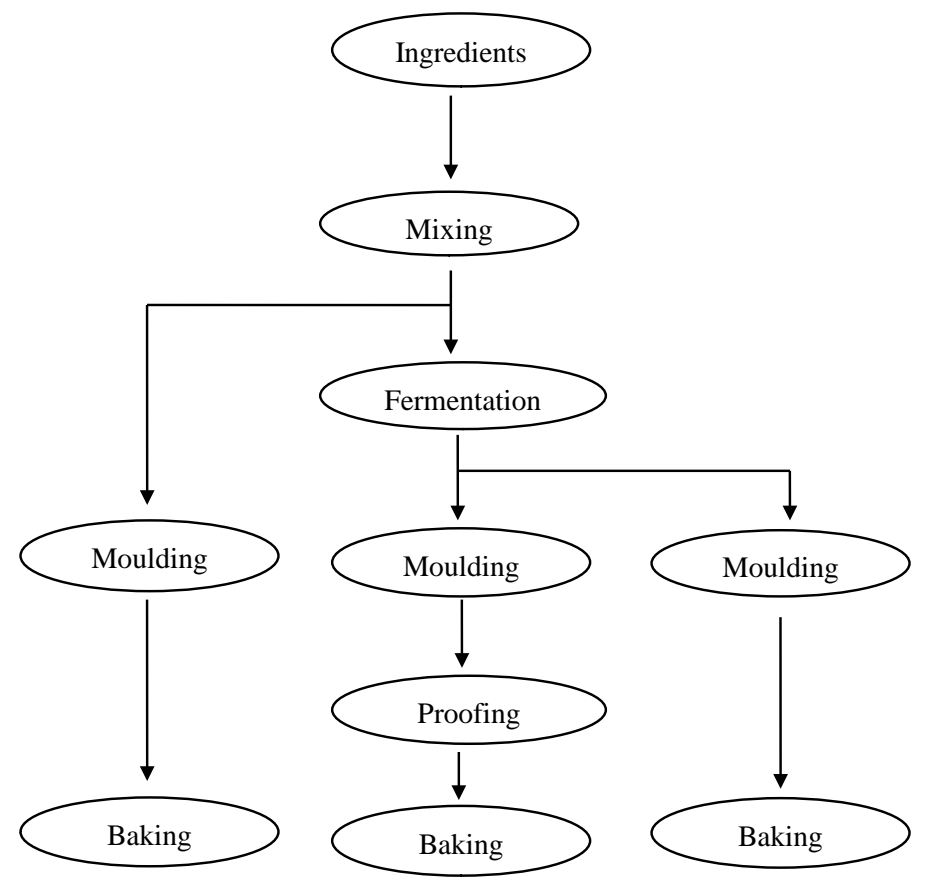

Figure 2. Flow sheet for the preparation of flat bread. 
Table 1. Flat breads of India.

\begin{tabular}{|c|c|c|c|}
\hline S.No. & Name of flat bread & Description & References \\
\hline 1 & Chapati & $\begin{array}{l}\text { Chapati is unleavened flatbread and is staple food of North Indian prepared normally } \\
\text { from whole wheat flour or maida. The sheeted Chapaties are bakes over hot iron plate } \\
\text { (Tawa) which is per-heated to about } 200^{\circ} \mathrm{C} \text {. Baking is done on one side to partial } \\
\text { cooking which is completed with the other side. The usual bake time is about } 1.5 \mathrm{~min} \text {. }\end{array}$ & $\begin{array}{l}{[1][2]} \\
{[6]-[8]}\end{array}$ \\
\hline 2 & Dosai & $\begin{array}{l}\text { Dosai is prepared from a fermented batter of rice and pulse. The ingredients are ground } \\
\text { finely and fermented for } 12-18 \mathrm{~h} \text { and baked to a thin dosai on a hot pan. The } \\
\text { thickness depends upon the consistency of batter in which wheat, sorghum, black } \\
\text { gram, green gram, bengal gram, maize and millet flour are often used along with basic } \\
\text { rice flour. The dosai is crisp tasty and has characteristic flavor. }\end{array}$ & [32] [33] \\
\hline 3 & Girda & $\begin{array}{l}\text { The Girda is the single layered flat bread based on flour, sour starter, baking soda, salt } \\
\text { and water. All the ingredients are mixed to form dough, fermented, moulded and baked } \\
\text { in tandoor. The Girda is brown in color due to its polishing the surface with skimmed } \\
\text { milk paste. The lines are also made on the upper side of Girda with the finger tips } \\
\text { usually } 7 \text { - } 9 \text { in number. }\end{array}$ & [34] \\
\hline 4 & Lavash & $\begin{array}{l}\text { Lavash is popular flatbread and is prepared from flour, water, yeast and sour starter. } \\
\text { Typical Lavash is } 60-70 \mathrm{~cm} \text { long, } 30-40 \mathrm{~cm} \text { diameter and } 2-3 \mathrm{~mm} \text { thick. The fixed } \\
\text { dough is fermented for } 1-3 \mathrm{hr} \text { The flattened dough is then baked in tandoor on its } \\
\text { walls for about } 1.5 \mathrm{~min} \text {. }\end{array}$ & [35] \\
\hline 5 & Naan & $\begin{array}{l}\text { Naan recipe contains flour, yeast, sugar, salt, yoghurt and fat. The ingredients after } \\
\text { mixing are allowed to ferment at normal temperature while covered with a wet cloth to } \\
\text { avoid drying up of the dough. The fermented dough is then sheeted manually into long, } \\
\text { thin flat pieces and baked in a tandoor for } 2 \text { min. at about } 315^{\circ} \mathrm{C} \text {. The Naans are very } \\
\text { soft when hot but after cooling they become leathery and difficult to chew. }\end{array}$ & [36] \\
\hline 6 & Parotha & $\begin{array}{l}\text { Parotha is a breakfast food item prepared in most of the Indian homes. It is normally } \\
\text { prepared from whole wheat flour with } 2.5 \% \text { salt, } 65 \% \text { water and } 40 \% \text { shortening. After } \\
\text { mixing, the dough is sheeted on the board with rolling pin and shaped round, square or } \\
\text { triangular. The sheeted dough (round) is smeared with fat and folded several times and } \\
\text { again flattened. The baking is done on preheated hot iron plate (Tawa) on both sides of } \\
\text { bread. }\end{array}$ & [4] \\
\hline 7 & Puri & $\begin{array}{l}\text { Slightly hard doughs are made for Puri which contains flour/whole wheat flour and fat. } \\
\text { The flattened doughs are lowered gently into pre-heated oil and after few seconds it is } \\
\text { pressed with the help of a slotted spatula to achieve full puffing. During frying the } \\
\text { sides may be changed for proper cooking and the final colour varies from golden } \\
\text { brown to brown depending upon the extraction rate. }\end{array}$ & [37] [38] \\
\hline 8 & Tandoori Roti & $\begin{array}{l}\text { Tandoori Roti is favourite flatbread of dhabas, consumed hot and generally heavier } \\
\text { than homemade Chapaties. The dough is made similar to Chapati dough but baked on } \\
\text { the sides of a heated tandoor which is placed on the ground. The sheeted dough is } \\
\text { pasted over the walls with a cloth pad and baked. }\end{array}$ & $\begin{array}{c}\text { [9] [25] } \\
\text { [39] }\end{array}$ \\
\hline
\end{tabular}

disrupted and transformed into a continuous cohesive visco-elastic gluten protein network [43]. This network is of the transient type, due to a dynamic exchange of disulfide bonds and entanglements between different protein polymers [35]. The protein network is mainly made up of glutenins, because native gliadins are globular proteins and, therefore, do not contribute to transient network formation. Due to network formation, resistance to dough mixing increases until an optimum is reached. The glutenin network is clearly the main network that accounts for the unique rheology of wheat flour based bread dough, but other biopolymers also participate in network formation at this stage of the bread making process, while as amylopectin and amylose from damaged starch may form a transient entanglement network [44] [45].

The mixing of flour partly depends upon the type of mixer used, its speed, water absorption and type of bread desired [14]. Changes in the swelling and water absorption properties of the dough can result in different processing behaviour during mixing [46]. The flat breads are more tolerant to under and over mixing. However, strong wheat flours when overmixed break the gluten, some disulphide bonds are broken to form the thiol radicals and the gluten proteins are partially depolymerized, resulting in greater solubility and the dough becomes sticky and difficult to handle or excessively stiff dough, leading to bread of inferior quality [47] [48]. However, undermixed dough have difficulty in sheeting due to under developed gluten matrix, less elastic with the result of bread with poor volume and do not proof satisfactorily.

Most of the flat breads produced in the world include fermentation as basic requirement, however, number of 
flat breads such as Parotha and some type of Chapaties are unleavened [2] [7]. Fermentation time after mixing was varied from 0 to $3 \mathrm{~h}$ at room temperature $\left(20^{\circ} \mathrm{C}-35^{\circ} \mathrm{C}\right)$. The optimum temperature-time combination is necessary to produce the quality end product. Fermentation is brought by the yeast or sourdough which consumes certain substances and produces some by products that affect the dough properties makes it lighter and extensible. The longer fermentation time is detrimental which alter the physical properties of the dough [11].

The moulding is the crucial step in flat bread production in which the dough is flattened into different shapes and sizes of uniform thickness. Each type of flat bread has different shape, size and small changes in the dough thickness produce quite variable product. However, these subsequent stages (sheeting and molding) cause subdivision of already existing gas cells, thus improving their number and size distribution [49]. Gas nuclei expand during fermentation due to release of fermentation gases, and during baking due to expansion of these gases as temperature increases. The dough is placed for a short proofing time but some flat bread is baked immediately after flattening. The proving and baking stages of bread making are characterized by fast biaxial expansion of gas cells, expanding at strain rates of $0.001-0.0001 / \mathrm{s}$ and $0.01-0.001 / \mathrm{s}$, respectively [9] [50].

Baking is the last but most important step in flat bread making process. Good baking quality is dependent on several rheological and physical/chemical properties of dough. A series of physical and chemical changes such as loss of moisture, volume expansion, starch gelatinization, protein denaturation, crust formation browning, rupturing of gas cells, etc., takes place during the baking operation [21]. The extent of starch granule hydration, swelling, dispersion, and the extent of reassociation are affected by the heating rate during baking. During baking, starch gelatinisation and pasting and heat setting of gluten proteins occur, resulting in the typical solid foam structure of baked bread [51]. The combination of heat, moisture and time during baking induces starch gelatinisation and pasting, which, in bread dough, starts at about $65^{\circ} \mathrm{C}$. Gelatinisation and pasting proceed over a broad temperature range and the partially crystalline starch is transformed into completely amorphous, transient, gelatinised starch entanglement network.

Temperature is the dominating factor in various physiochemical changes during baking [49]. To achieve the optimal baking, the common industrial practice is to bake bread in the oven controlled at a constant temperature. The quality and shelf life of bread is affected by the time and temperature of the baking process. The oven temperatures are kept high in the range of $350^{\circ} \mathrm{C}-550^{\circ} \mathrm{C}$ for producing good quality flat breads. However, they are baked in short time and retain more moisture and softness.

Number of techniques have been used for the baking of flat bread. Traditionally tandoor are used for the commercialization of tandoor flat breads, whereas, at home scale tawa is mostly used for the preparation of Chapati. The baking ovens have been developed with diffeent range temperatures for flat bread production and various authors have developed the baking procedures and equipments [49] [52] [53].

To cope up with the increasing demand for flat breads, mechanization of preparation becomes necessary to produce ready-to-eat bread with assuring the quality of the products. To cater to these needs, sound scientific studies that throw light on different properties of these products have to be systematically planned to obtain necessary details that would help in the realisation of large scale production through mechanization. Sridhar and Manohar [54] developed and optimized the working of continuous Chapati making machine of $4 \mathrm{HP}$ with maximum production capacity of $160 \mathrm{~kg} / \mathrm{h}$ of dough extrusion at the optimum moisture content of $65 \%-70 \%$ [55]. The process conditions were optimized for the automatic production of Chapati based on minimum specific energy and maximum puffing index. The need for mechanization of production of other flat breads is also high; hence, studies have to be focused on different processing parameters and its optimization for the mass production. This is the potential area to popularize and commercialize the flat bread production.

\section{Dough Rheology}

The rheological characteristics of dough are important, as they affect both the machinability of the dough and the quality of the end product. The rheological properties of dough depend on the chemical composition of flour and nature of other ingredients added [4] [10]. It evaluates the functional properties of flour, viscosity, elasticity and plasticity, which relate to dough behavior during processing operations [56]. However, dough should meet certain rheological requirements in order to produce high quality flat bread with prolonged shelf-life. Among the rheological characteristics, farinograph dough stability, extensograph ratio and area, mixograph peak height, compressive stress, dough hardness and cohesiveness are affected by the nature of the flour [4]. The rheological properties of dough change significantly during baking operation, mainly as the result of the temperature 
induced changes in the molecular structures.

The rheological properties of bread dough have been widely characterised experimentally. Firstly, viscosity and eventually elasticity have been thoroughly measured at ambient and/or constant temperatures. When applied, heating rates have been appropriate to the bread core [57], and rarely to the crust, the highest comparable values being $9^{\circ} \mathrm{C}-11^{\circ} \mathrm{C} / \mathrm{min}$ [58] [59]. Secondly, bread dough has been characterised at very low uniaxial shear rates (between $10^{-2}$ and $10^{-3} \mathrm{~s}^{-1}$ ) [56] and more recently under biaxial extension at rates of $5 \times 10^{-2} \mathrm{~s}^{-1}$ [60] and $10^{-1}$ $\mathrm{s}^{-1}$ [61]. Most of these strain rates failed to reproduce those encountered during baking $\left(1-2 \times 10^{-3} \mathrm{~s}^{-1}\right)$ [56]. With the exception of biaxial extension [62], other tests used in combination with dynamic heating only approximately reproduce the expected deformation of dough films over a gas bubble during baking. Finally, rheological measurements applicable to the crust should ideally be conducted under dynamic drying; again most of the data available were obtained at a constant water content, with levels relevant to the dough [56]. Effects of baking ingredients like salt, shortening, yeast and non-fat dry milk on the farinograph characteristics of wheat flour have been reported by Hug-Iten et al. [63]. The extensograph has been used extensively to study the effects of a wide range of ingredients on the rheological properties of wheat flour. Sai and Rao [64] studied the effects of major ingredients like salt, yeast shortening on the rheological characteristics of wheat flour dough.

\section{Nutritional Value of Flat Bread}

The nutritive value of flat bread depends entirely on the chemical composition of the flour and other ingredients used for its preparation. Optional ingredients can be added to improve processing or to produce specially and novelty breads which often have an increased nutritional value [1] [6]. Wheat flour is the main constituent of flat breads which affects its nutritional quality. Wheat flour of different extraction rates are used for the production of flat bread which has marked significant effect on its nutritional profile [5]. The minerals content and other phytochemical concentration are reduced in flat breads by using lower extraction rate wheat flour. With an increase in exaction rate, the protein content, fiber, sugar, lipids and mineral matter increase, whereas the starch content decreases [19] [23]. Chapati prepared from whole wheat flour has reported to be having higher level of nutrients and minerals [6] [25].

Flat breads are also supplemented with various nutritious substances which are gaining popularity nowadays worldwide [3]. Incorporation of cereal grains, legumes and other fruit and vegetable crops in flat breads are considered as functional foods because they are convenient vehicles for carrying important nutrients and photochemicals [1] [3]. Inclusion of Bengal gram flour and desi ghee, which is an excellent source of fat-soluble vitamins, improved the Chapati nutritional quality [65]. Incorporation of soy, peanut and cottonseed flours increased the protein content of Chapaties. Soy, peanut and cotton seed flour incorporation at $10 \%$ and $20 \%$ level increased the available lysine content of chapaties [66]. Concentration of minerals namely P, Zn, Fe, Mn and Ca and protein efficiency ratio increased in Chapaties supplemented with either chickpea or pigeon pea flour [17].

With the aim of increasing the nutritive value of Puri, many of the supplementations are generally followed and effect on the nutrient availability was studied. It was found that the Puris can be prepared by incorporation of amaranth (Amaranthus tricolor) leaves to increase the Ca, Fe and $\beta$-carotene availability in the daily diet [67]. Harpreet et al. [68] have analysed the availability of some of the minerals in Parotha. To enhance the vitamin A content, Parotha was prepared out of deacidified and deodourised palm oil, a rich source of $\beta$-carotene.

Consumer's quality perception of flat bread is mainly determined by sensory and health attributes. Because the increase awareness of a healthy lifestyle, breads containing whole grain, multi-grain or other functional ingredients are becoming more important in the market. The nutritive value of flat breads has been increased by incorporating rye, barley, and oats into the bread formula. The availabilities and levels of bioactive compounds in cereal grains can decrease or increase during the bread production [3]. The interactions between bread and companion foods are also important and affect the nutritional value of bread [45].

\section{Flavor}

Flavor compounds are key elements for consumer acceptance and product identification in flat bread. The flavor perception perceived while eating involves complex interactions between sensory sensations of olfaction, taste and trigeminal stimuli [69]. Sensory quality is the ultimate criterion for the acceptance of breads and conesquently the quality built during processing must last throughout the distribution chain and until the stage of consumption [70]. Among the various intrinsic properties of flat bread, volatile flavor compounds play a key 
role in the perception of fresh bread flavor. However, the perceived fresh bread flavor often relies on the type of bread, ingredients and method of production.

Volatile components responsible for the aroma of freshly baked bread are also an area which has attained much attention [71]. More than 300 volatile components related to bread flavor have been identified [69]. These components belong to different chemical classes and the most important chemical groups are aldehydes, alcohols, ketones, esters, acids, pyrazines, and pyrrolines together with hydrocarbons, furans, and lactones [69] [72].

One category of speciality breads, the sourdoughs have a fermentation process affected by a complex microflora of yeasts and lactic acid bacteria which confer specific flavor characteristics. The main contributors to development of flavor compounds in dough are enzyme activity and fermentation. Enzymes produce precursors directly or indirectly involved in flavor forming processes [73] while yeast fermentation is responsible for the formation of a number of alcohols, acids, and esters [74]. The biochemical activity of microflora in the sourdough, resulting in higher production of organic acid and flavoring compounds [72]. Higher extraction rate of flour results in higher production of lactic and acetic acids. The final acid values in sourdough made from whole meal flour are almost double the values in sourdough made from straight grade flours [75].

\section{Shelf Life}

The freshness of flat bread is the holistic attribute and is prized for its taste, aroma and texture. Because of the lean formula flat bread stale quickly during storage and shelf life is limited to few hours [76], resulting from the physiochemical changes that lead to a loss of freshness with an increased firmness and an alteration of its organoleptic quality, and becomes difficult to chew which is considered objectionable in acceptance by consumers [3]. Due to an increasing consumer demand for fresh flat breads, new technologies and processing conditions have been developed to avoid these undesirable changes and to extend shelf life [77]. One method involves the addition of particular components, such as emulsifiers, hydrocolloids, and enzyme preparations to the recipe [78]. Another method applied to prevent bread staling consists of modifying the process conditions so as to offer the consumer fresh bread at any time.

Several works showed that bread staling was closely associated to starch retrogradation [79] [80]. However, others have suggested a mechanism about bread staling dealing with the increase of interactions between starch molecules and gluten proteins [81]. Later, it was shown that the addition of gluten in model systems did not change firming rate [82]. Although considerable progress in dissecting the staling process has occurred, bread staling remains intensively studied, yet not well understood, phenomenon. Even though starch seems to be a key player in the staling phenomenon, interactions between starch and other ingredients of the matrix seem to occur. The retrogradation of amylose occurs during the first hours following baking. Amylopectin retrogradation occurs in the long term and seems to be the major phenomenon involved in bread firming. Still, staling rate can be delayed by using specific ingredients such as shortening and emulsifiers that will delay the retrogradation of the starch components.

Staling involves hardening of the crumb that is a complex phenomenon in which multiple mechanisms operate. Factors affecting wheat bread crumb staling have been extensively investigated [83]. However, many studies have shown that starch retrogradation is not the only factor responsible for crumb staling [84]. Water plays a critical role in bread staling. When the retrogradation of amylopectin occurs, water molecules are incorporated into the crystallites and the distribution of water is shifted from gluten to starch linkages, thereby changing the nature of gluten network [85]. In addition to the molecular order of starch, water also plays an important role in crumb firmness due to its plasticizing effect on the crumb network [86].

Flat breads are consumed fresh as they stale rapidly on storage. With rapidly changing lifestyles, increasing urbanization and industrialization and changing socio-economic trends, there is an increase in the demand for convenience foods, which require less preparation time. Large-scale production of flat breads calls for mechanization and marketing of this flat bread in suitable unit packs. When it reaches the consumer, the packed flat breads should retain all the sensory characteristics of fresh bread [79].

The addition of emulsifiers has been also used by several authors to increase the shelf life of flat breads. Glycerol monostearate (GMS) and sodium stearoyl lactate (SSL) were used to retards the staling of starch in the Chapaties stored at ambient and refrigerated temperature [17]. The percentage reduction of moisture content in glycerol monostearate-containing Chapati during storage at ambient was less as compared to control samples. This is due to the ability of glycerol monostearate to form a complex with helical regions of starch, i.e., the 
straight-chain hydrophobic portion of emulsifiers will complex with the helical section of amylose and amylopectin [87]. This change was attributed to the addition of SSL and GMS which reduced the extent of solubilisation of starch molecules upon heating in excess water [88].

Surfactants have ability to form complexes with amylose and amylopectin linkages which leads to softening of bread [89]-[91]. The higher degree of softness in the emulsified Chapaties compared to non-emulsified Chapaties is reported in literature [17]. Hydrocolloids have been also used for shelf life enhancement of flat breads. Among the hydrocolloids, guar gum increased the extensibility of fresh as well as stored Chapati [18]. The addition of $1 \% \mathrm{w} / \mathrm{w}$ of guar gum also retarded the staling of Chapaties both at $29^{\circ} \mathrm{C}$ and refrigerated temperature storage. All the anti staling additives and water, play a role of plasticizer, thereby preventing the rigidity of macromolecular starch and gluten chains and hence enhancing the shelf life of flat breads.

Different wrapping materials have been used for the packaging of flat breads. Fresh Chapati was soft and extensible as indicated by low force values required to deform, low modulus of deformation and longer distances of extension before rupture. The Chapati stored for $24 \mathrm{~h}$ was hard and brittle as indicated by the high force values, high modulus of deformation and short distances of extension before rupture. The packaged Chapati was sealed decrease the extensibility could not be attributed to the loss in moisture but to recrystallization and retrogradation of starch in the Chapati, a very common phenomenon that occurs in bread [92].

There is a considerable potential for the large-scale manufacture and marketing of Parotha, as the demand for ready-to-eat convenience food products have been steadily increasing because of industrialization. It calls for mechanization in the preparation and distribution in unit packs. For achieving the objective of commercial marketing, it is desirable that the Parotha should have adequate shelf-life. For extending the shelf-life of any product, knowledge regarding the changes taking place in the product during storage is necessary.

\section{Conclusion}

For centuries, baked cereal products have been widely consumed throughout the world. Among these, flat bread is the most popular because of its nutritional value, textural properties and easiness to produce. They are generally consumed fresh. However, flat bread is characterized by a relatively short life, resulting from physiochemical changes that lead to a loss of freshness with an increased firmness and an alteration of its organoleptic quality, thus becoming difficult to chew. Due to an increasing consumer demand for fresh bread, new technologies have been developed to avoid or delay these undesirable changes and to extend the shelf life. The suitability of different wheat varieties and extraction rates have been assessed for the suitable flat bread production technology. They have also optimized on the basis of flour type, manner of sheeting or in the appearance of end product. Different baking operations and formulations have been standardized to evaluate the flat breads.

\section{References}

[1] Dhingra, S. and Jood, S. (2001) Organoleptic and Nutritional Evaluation of Wheat Breads Supplemented with Soyabean and Barley Flour. Food Chemistry, 77, 479-288.

[2] Rehman, S., Paterson, A. and Piggot, J.R. (2007) Chapatti Quality from British Wheat Cultivar Flours. LWT-Food Science and Technology, 40, 775-784. http://dx.doi.org/10.1016/j.lwt.2006.04.009

[3] Gujral, H.S. and Pathak, A. (2002) Effect of Composite Flours and Additives on the Texture of Chapatti. Journal of Food Engineering, 55, 173-179. http://dx.doi.org/10.1016/S0260-8774(02)00061-4

[4] Indrani, D. and Rao, G.V. (2000) Effect of Chemical Compositions of Wheat Flour and Functional Properties of Dough on the Quality of South Indian Parotta. Food Research International, 33, 875-881. http://dx.doi.org/10.1016/S0963-9969(00)00117-4

[5] Saxena, D.C., Salimath, P.V. and Rao, H.P. (2000) Indian Wheat Cultivars: Their Carbohydrate Profile and Its Relation to Tandoori Roti Quality. Food Chemistry, 68, 185-190. http://dx.doi.org/10.1016/S0308-8146(99)00174-0

[6] Gocmen, D., Inkaya, A.N. and Aydin, E. (2009) Flat Breads. Bulgarian Journal of Agricultural Science, 15, $298-306$.

[7] Dhaliwal, V.S., Hatcher, D.W., Sekhon, K.S. and Kruger, J.E. (1996) Methods for Preparation and Testing of Chapattis Produced from Different Classes of Canadian Wheat. Food Research International, 29, 163-168. http://dx.doi.org/10.1016/0963-9969(96)00004-X

[8] Gujral, H.S., Haros, M. and Rosell, C.M. (2004) Improving the Texture and Delaying Staling in Rice Flour Chapatti with Hydrocolloids and Amylase. Journal of Food Engineering, 65, 89-94. http://dx.doi.org/10.1016/j.jfoodeng.2003.12.007 
[9] Singh, N., Singh, H., Kaur, K. and Bakshi, M.S. (2000) Determining the Effect of Degree of Polish and Ash Distribution in Brown Rice Using Conductivity. Food Chemistry, 69, 147-151. http://dx.doi.org/10.1016/S0308-8146(99)00237-X

[10] Indrani, D. and Rao, G.V. (2003) Influence of Surfactants on Rheological Characteristics of Dough and Quality of Parotta. International Journal of Food Science and Technology, 38, 47-54. http://dx.doi.org/10.1046/j.1365-2621.2003.00630.x

[11] Qarooni, J. (1996) Flat Bread Technology. Springer, Heidelberg, 206. http://dx.doi.org/10.1007/978-1-4613-1175-1

[12] Zanoni, B. and Peri, C. (1993) A Study of the Breading Baking Process. I: A Phenomenological Model. Journal of Food Engineering, 19, 389-394. http://dx.doi.org/10.1016/0260-8774(93)90027-H

[13] Srivastava, A.K., Meyer, D., Rao, H. P. and Seibel, W. (2002) Scanning Electron Microscopic Study of Dough and Chapatti from gluten-Reconstituted Good and Poor Quality Flours. Journal of Cereal Science, 35, 119-128. http://dx.doi.org/10.1006/jcrs.2001.0432

[14] Cauvain, S.P., and Collins, T.H. (1995) Mixing, Moulding and Processing Bread Dough. Baking Industry Europe, London, 41-43.

[15] Mayers, D.K. and Attfield, P.V. (1999) Intercellular Concentration of Exogenous Glycerol in Saccharomyces cerevisiae Provides for Improved Leaving in Frozen Sweet Doughs. Food Microbiology, 16, 45-51. http://dx.doi.org/10.1006/fmic.1998.0212

[16] Khaniki, G.H.R.J., Vaezi, F., Yunesian, M., Nabizadeh, R. and Paseban, G.H.R. (2007) Dectection of Baking Soda in Flat Bread by Direc pH Metery and Alkalinity Measurement. Journal of Applied Science, 22, 3584-3587.

[17] Sharma, S., Sekhon, K.S. and Nagi, H.P.S. (1995) Sensory Characteristics and Storage Quality of Flat Bread from Indian Wheats. Chemie Mikrobiologie Technologie der Lebensmittel, 17, 156-160.

[18] Shalini, G.K. and Laxmi, A. (2007) Influence of Additives on Rheological Characteristics of Whole Wheat Dough and Quality of Chapati (Indian Unleavened Flat Bread) Part 1-Hydrocolloids. Food Hydrocolloids, 21, 110-117. http://dx.doi.org/10.1016/j.foodhyd.2006.03.002

[19] Ghodke, S.K., Ananthanarayan, L. and Rodrigues, L. (2009) Use of Response Surface Methodology to Investigate the Effects of Milling Conditions on Damages Starch, Dough Stikness and Chapatti Quality. Food Chemistry, 112, 1010 1015. http://dx.doi.org/10.1016/j.foodchem.2008.05.036

[20] Brown, J. (1993) Advances in Bread Making Technology. In: Kamel, B.S. and Stauffer, C.E., Eds., Advances in Baking Technology, Blackie Academic and Professional, Glasgow, 38-87. http://dx.doi.org/10.1007/978-1-4899-7256-9_3

[21] Mondal, A. and Datta, A.K. (2008) Bread Baking-A Review. Journal of Food Engineering, 86, 465-476. http://dx.doi.org/10.1016/j.jfoodeng.2007.11.014

[22] Shurpalekar, S.R., Kumar, G.V., Rao, G.V., Ranga Rao, G.C.P., Vatsala, C.N. and Rahim, A. (1976) Physio-Chemical, Rheological and Milling Characteristics of Bread and Chapatti Making Quality of Indian Wheat. Journal of Food Science and Technology, 13, 79-86.

[23] Salmenkallio-Martila, M., Katina, K. and Autio, K. (2001) Effect of Bran Fermentation on Quality and Microstructure of High Fibre Wheat Bread. Cereal Chemistry, 78, 429-435. http://dx.doi.org/10.1094/CCHEM.2001.78.4.429

[24] Rao, H., Leelavathi, K. and Shurpalekar, S.R. (1986) Test Baking of Chapatti Development of a Method. Cereal Chemistry, 63, 297-303.

[25] Qarooni, J., Posner, E.S. and Ponte, J.G. (1993) Production of Tanoori Bread with Hard White and Other US Wheat. Lebensmittel-Wissenschoftund Technology, 26, 100-106.

[26] Pratt, D.B. (1971) Criteria of Flour Quality. In: Pomeranz, Y., Ed., Wheat Chemistry and Technology. American Association of Cereal Chemists, St. Paul, 201-226.

[27] Eliasson, A.C. and Larsson, K. (1993) Cereals in Breadmaking. Marcel Dekker, New York.

[28] Morris, C.F. and Rose, S.P. (1996) Wheat. In: Henry, R.J. and Kettlewell, P.S., Eds., Cereal Grain Quality, Chapman and Hall, London, 3-54. http://dx.doi.org/10.1007/978-94-009-1513-8 1

[29] Izydorczkyand, M.S. and Biliaderis, C.G. (1995) Cereal Arabinoxylans Advances in Structure and Physio-Chemical Properties. Carbohydrate Polymers, 28, 33-48. http://dx.doi.org/10.1016/0144-8617(95)00077-1

[30] Sidhu, J.S., Al-Hooti, S.N. and Al-Saqer, J.M. (1999) Effect of Adding Wheat Bran and Germ Fractions on the Chemical Composition of High Fibre Toast Bread. Food Chemistry, 67, 365-371. http://dx.doi.org/10.1016/S0308-8146(99)00123-5

[31] Scanlon, M.G. and Zghal, M.C. (2001) Bread Properties and Crumb Structure. Food Research International, 34, 841864. http://dx.doi.org/10.1016/S0963-9969(01)00109-0 
[32] Ramakrishnan, C.V. (1977) The use of fermented foods in India. In: Steinkraus, K., Cullen, R.E., Pederson, C.S. and Nelis, L.F., Eds., Handbook of Indigenous Fermented Foods, Marcel Dekker, New York, 131-146.

[33] Nagaprabha, P. and Prakash, J. (2009) Development and Quality Assessment of Green Gram Based Instant Dosai Mix. Journal of Food Science and Technology, 46, 418-422.

[34] Mir, S.A. (2011) Flat Breads of Kashmir Valley. M.Sc. Thesis, Islamic University of Science and Technology, Awantipora, Jammu and Kashmir.

[35] Gargari, B.P., Mahboob, S. and Razavieh, S.V. (2007) Content of Phytic Acid and Its Mole Ratio to Zinc in Flour and Breads Consumed in Tabriz, Iran. Food Chemistry, 100, 1115-1119. http://dx.doi.org/10.1016/j.foodchem.2005.11.018

[36] Ezekiel, R. and Singh, N. (2011) Use of Potato Flour in Bread and Flat Bread. In: Preedy, V., Watson, R. and Patel, V., Eds., Flour and Breads and Their Fortification in Health and Disease Prevention, Academic Press, New York, 247-259.

[37] Shurpalekar, S.R. and Shukla, V.K. (1992) Characteristics of Puri Dough and Puri Based on Wheat and Composite Flours. Journal of Food Science and Technology, 29, 153-158.

[38] Parimala, K.R. and Sudha, M.L. (2012) Effect of Hydrocolloids on the Rheological, Microscopic, Mass Transfer Characteristics during Frying and Quality Characteristics of Puri. Food Hydrocolloids, 27, 191-200. http://dx.doi.org/10.1016/j.foodhyd.2011.07.005

[39] Qarooni, J., Ponte, J.G. and Posner, E.S. (1992) Flat Breads of the World. Cereal Foods World, 37, 863-885.

[40] Tipples, K.H. (1975) Breadmaking Technology. In: Grains and Oilseeds: Handling, Marketing, Processing, 2nd Edition, Canadian International Grains Institute, Winnipeg, 497-540.

[41] Gan, Z., Angold, R.E., Williams, M.R., Ellis, P.R., Vaughan, J.G. and Galliard, T. (1990) The Microstructure and Gas Retention of Bread Dough. Journal of Cereal Science, 12, 15-24. http://dx.doi.org/10.1016/S0733-5210(09)80153-7

[42] Kokelaar, J.J. and Prins, A. (1995) Surface Rheological Properties of Bread Dough Components in Relation to Gas Bubble Stability. Journal of Cereal Science, 22, 53-61. http://dx.doi.org/10.1016/S0733-5210(05)80007-4

[43] Singh, H. and MacRitchie, F. (2001) Application of Polymer Science to Properties of Gluten. Journal of Cereal Science, 33, 231-243. http://dx.doi.org/10.1006/jcrs.2000.0360

[44] Slade, L. and Levine, H. (1993) Water Relationship in Starch Transitions. Carbohydrate Polymers, 21, 105-131. http://dx.doi.org/10.1016/0144-8617(93)90006-P

[45] Dewettinck, K., Van Bockstaele, F., Kuhne, B., Van de Walle, D., Courtens, T.M. and Gellynck, X. (2008) Nutritional Value of Bread: Influence of Processing, Food Interaction and Consumer Perception. Journal of Cereal Science, 48, 243-257. http://dx.doi.org/10.1016/j.jcs.2008.01.003

[46] Haseborg, E. and Himmelstein, A. (1988) Quality Problems with High Fibre Breads Solved by Using Hemicellaulase Enzymes. Cereal Foods World, 33, 419-422.

[47] Giannou, V.K., Essoglou, V. and Tzia, C. (2003) Quality and Safety Characteristics of Bread Made from Frozen Dough. Trends in Food Science and Technology, 14, 99-108. http://dx.doi.org/10.1016/S0924-2244(02)00278-9

[48] Asghar, A., Anjum, F.M., Butt, M.S. and Hussain, S. (2005) Functionality of Different Surfactants and Ingredients in Frozen Dough. Turkey Journal of Biology, 69, 397-402.

[49] Qarooni, J., Orth, R.A. and Watoon, M. (1987) A Test Baking Technique for Arabian Bread Quality. Journal of Cereal Science, 6, 69-80. http://dx.doi.org/10.1016/S0733-5210(87)80042-5

[50] Dobraszczyk, B.J. (1997) The Rheological Basis of Dough Stickiness. Journal of Texture Studies, 28, 139-162. http://dx.doi.org/10.1111/j.1745-4603.1997.tb00108.x

[51] Hoseney, R.C., Lineback, D.R. and Seib, P.A. (1978) Role of Starch in Baked Foods. Bakers Digest, 53, 11.

[52] Haridas Rao, P., Leelavathi, K. and Shurpalekar, S.R. (1986) Objective Measurements of the Consistency of Chapati Dough Using a Research Water Absorption Meter. Journal of Texture Studies, 17, 401-420. http://dx.doi.org/10.1111/j.1745-4603.1986.tb00561.x

[53] Farvili, N., Walker, C.E. and Qarooni, J. (1997) The Effects of Protein Content of Flour and Emulsifiers on Tanoor Bread Quality. Journal of Cereal Science, 26, 137-143. http://dx.doi.org/10.1006/jcrs.1996.0112

[54] Sridhar, B.S. and Manohar, B. (2001) Optimization of the Continuously Extruded Unleavened Flat Bread (Chapati) Process. European Food Research and Technology, 212, 477-486. http://dx.doi.org/10.1007/s002170000280

[55] Saxena, D.C., Rao, P.H. and Raghava, R. (1995) Analysis of Modes of Heat Transfer in Tandoor Oven. Journal of Food Engineering, 26, 209-217. http://dx.doi.org/10.1016/0260-8774(94)00057-G

[56] Bloksma, A.H. (1995) Rheology of the Breadmaking Process. Cereal Foods World, 35, 228-236.

[57] Collar, C., Bollain, C. and Rosell, C.M. (1980) Rheological Behaviour of Formulated Bread Doughs during Mixing and Heating. Food Science and Technology International, 13, 99-107. http://dx.doi.org/10.1177/1082013207078341

[58] Bloksma, A.H. (1980) Effect of Heating Rate on Viscosity of Wheat Flour Doughs. Journal of Texture Studies, 10, 
261-269. http://dx.doi.org/10.1111/j.1745-4603.1980.tb00252.x

[59] Singh, A.P. and Bhattacharya, M. (2005) Development of Dynamic Modulus and Cell Opening of Dough During Baking. Journal of Texture Studies, 36, 44-67. http://dx.doi.org/10.1111/j.1745-4603.2005.00003.x

[60] Rouille, J., Della Valle, G., Lefebvre, J., Sliwinski, E. and Van Vliet, T. (2005) Shear and Extensional Properties of Bread Doughs Affected by Their Minor Components. Journal of Cereal Science, 42, 45-57. http://dx.doi.org/10.1016/j.jcs.2004.12.008

[61] Dobraszczyk, B.J. and Salmanowicz, B.P. (2008) Comparison of Predictions of Baking Volume Using Large Deformation Rheological Properties. Journal of Cereal Science, 47, 292-301. http://dx.doi.org/10.1016/j.jcs.2007.04.008

[62] Dobraszczyk, B.J. and Morgenstern, M.P. (2003) Rheology and the Bread Making Process. Journal of Cereal Science, 38, 229-245. http://dx.doi.org/10.1016/S0733-5210(03)00059-6

[63] Hug-Iten, S., Handschin, S., Conde-Petit, B. and Escher, F. (1999) Changes in Starch Microstructure on Baking and Staling of Wheat Bread. LWT-Food Science and Technology, 32, 255-260. http://dx.doi.org/10.1006/fstl.1999.0544

[64] Sai, M.R. and Rao, P.A. (1999) Effect of Emulsifiers, Fat Level and Type on the Rheological Characteristics of Biscuit Dough and Quality of Biscuits. Journal of the Science of Food and Agriculture, 79, 1223-1231. http://dx.doi.org/10.1002/(SICI)1097-0010(19990715)79:10<1223::AID-JSFA346>3.0.CO;2-W

[65] Balmeer, S.G., Navdeep, S.S. and Manmeet, K. (2005) Effect of Chickpea, Ghee, Sodium Chloride, Mixing Time and Resting Time on Instrumental Texture and Sensory Quality of Chapati. Journal of Food Science and Technology, 42, 481-488.

[66] Bhat, C.M. and Vivian, V.M. (1980) Effect of Incorporation of Soy, Peanut and Cottonseed Flours on the Acceptability and Protein Quality of Chapaties. Journal of Food Science and Technology, 17, 168-171.

[67] Darshan, P., Shashikala, Y., Manju, G. and Khetarpaul, N. (2004) Nutrient Composition of Amaranth (Amaranthus tricolor) and Kondhara (Digeria arvensis) Leaves and Their Products. Journal of Food Science and Technology, 41, 563-566.

[68] Grewal, K.H., Hira, C.K. and Kawatra, B.L. (1999) Zinc, Calcium and Iron Availability Using Molar Ratios in Processed and Cooked Wheat Products. Journal of Food Science and Technology, 36, 453-456.

[69] Pozo-Bayon, M.A., Guichard, E. and Cayot, N. (2006) Flavor Control in Baked Cereal Products. Food Reviews International, 22, 335-379. http://dx.doi.org/10.1080/87559120600864829

[70] Jensen, S., Oestdal, H., Skibsted, L.H., Larsen, E. and Thybo, A.K. (2011) Chemical Changes in Wheat Pan Bread during Storage and How It Affects the Sensory Perception of Aroma, Flavour, and Taste. Journal of Cereal Science, $\mathbf{5 3}$, 259-268. http://dx.doi.org/10.1016/j.jcs.2010.11.007

[71] Schieberle, P. and Grosch, W. (1991) Potent Odorants of the Wheat Bread Crumb Differences to the Crust and Effect of a Longer Dough Fermentation. Zeitschrift fur Lebensmittel-Untersuchung und Forschung, 192, 130-135. http://dx.doi.org/10.1007/BF01202626

[72] Hansen, A. and Hansen, B. (1994) Influence of Wheat Flour Type on the Production of Flavour Compounds in Wheat Sourdoughs. Journal of Cereal Science, 19, 185-190. http://dx.doi.org/10.1006/jcrs.1994.1025

[73] Martinez-Anaya, M.A. (1994) Enzymes in Bread Flavour. Journal of Agricultural and Food Chemistry, 44, $2469-2480$. http://dx.doi.org/10.1021/jf960020d

[74] Hazelwood, L.A., Daran, J.M., Van Maris, A.J.A., Pronk, J.T. and Dickinson, J.R. (2008) The Ehrlich Pathway for Fusel Alcohol Production: A Century of Research on Saccharomyces Cerevisiae Metabolism. Applied and Environmental Microbiology, 74, 2259-2266. http://dx.doi.org/10.1128/AEM.02625-07

[75] Rehman, S., Paterson, A. and Piggott, J.R. (2006) Flavour in Sourdough Breads: A Review. Trends in Food Science \& Technology, 17, 557-566. http://dx.doi.org/10.1016/j.tifs.2006.03.006

[76] Sidhu, J.S., Al-Saqer, J. and Al-Zenki, S. (1997) Comparison of Methods for Assessment of the Extent of Staling in Bread. Food Chemistry, 58, 161-167. http://dx.doi.org/10.1016/S0308-8146(96)00196-3

[77] Fik, D.S. (2002) Dynamic Mechanical Analysis of Glass Transitions in Long Shelf Life Bread. Journal of Food Science, 131, 1121-1126.

[78] Barcenas, M.E., Haros, M. and Rosell, C.M. (2003) An Approach to Studying the Effect of Different Bread Improvers on the Staling of Prebaked Frozen Breads. European Food Research and Technology, 218, 56-61. http://dx.doi.org/10.1007/s00217-003-0816-y

[79] Kim, S.K. and D’Appolonia, B.L. (1977) Bread Staling Studies. III. Effects of Pentosans on Dough, Bread, and Bread Staling Rate. Cereal Chemistry, 54, 225-229.

[80] Inagaki, T. and Seib, P.A. (1992) Firming of Bread Crumb with Cross-Linked Waxy Barley Starch Substituted for Wheat Starch. Cereal Chemistry, 69, 321-325. 
[81] Martin, M.L., Zeleznak, K.J. and Hoseney, R.C. (1991) A Mechanism of Bread Firming. I. Role of Starch Firming. Cereal Chemistry, 68, 498-503.

[82] Duran, E., Leon, A. and Barber, C.B. (2001) Effect of Low Molecular Weight Dextrins on Gelatinization and Retrogradation of Starch. European Food Research and Technology, 212, 203-207. http://dx.doi.org/10.1007/s002170000205

[83] Zobel, H.F. and Kulp, K. (1996) The Staling Mechanism. In: Hebeda, R.E. and Zobel, H.F., Eds., Baked Goods Freshness, Marcel Dekker, New York, 1-64.

[84] Baik, M.Y. and Chinachoti, P. (2000) Moisture Redistribution and Phase Transitions during Bread Staling. Cereal Chemistry, 77, 484-488. http://dx.doi.org/10.1094/CCHEM.2000.77.4.484

[85] Gray, J.A. and BeMiller, J.N. (2003) Bread Staling: Molecular Basis and Control. Comprehensive Reviews in Food Science and Food Safety, 2, 1-21. http://dx.doi.org/10.1111/j.1541-4337.2003.tb00011.x

[86] Hug-Iten, S., Escher, F. and Conde-Petit, B. (2003) Staling of Bread: Role of Amylose and Amylopectin and Influence of Starch Degrading Enzymes. Cereal Chemistry, 80, 654-661. http://dx.doi.org/10.1094/CCHEM.2003.80.6.654

[87] Nuessli, J., Handschin, S., Conde-Petit, B. and Escher, F. (2000) Rheology and Structure of Amylopectin Potato Starch Dispersions without and with Emulsifier Addition. Starch/Starke, 52, 22-27. http://dx.doi.org/10.1002/(SICI)1521-379X(200001)52:1<22::AID-STAR22>3.0.CO;2-I

[88] Ghiasi, K., Hoseney, R.C. and Varriano-Marston, E. (1982) Gelatinization of Starch II. Starch Surfactant Interaction. Cereal Chemistry, 59, 86-88.

[89] Krog, N. and Jensen, B.N. (1970) Interaction of Monoglycerides in Different Physical States with Amylose and then Antifirming Effects in Bread. International Journal of Food Science \& Technology, 5, 77-87. http://dx.doi.org/10.1111/j.1365-2621.1970.tb01544.x

[90] Lagendijk, J. and Penning, H.J. (1970) Relation between Complex Formation of Starch with Monoglycerides and the Firmness of Bread. Cereal Science Today, 15, 334-338.

[91] Lonkhuysen, V.H. and Blankstijn, N.J. (1974) Interaction of Monoglycerides with Starches. Starch/Starke, 26, 337-341. http://dx.doi.org/10.1002/star.19740261005

[92] Guy, R.C.E., Hodge, D.G. and Robb, J. (1983) An Examination of the Phenomenon Associated with Staling. FMBRA Report No.107, Nov., CFCA, Chipping Campden. 